\title{
PENINGKATAN MINAT BELAJAR SISWA KELAS IX MELALUI LAYANAN BIMBINGAN KELOMPOK DI SMP KRISTEN 1 SALATIGA
}

\author{
Yohanes Eka Puspawan ${ }^{1}$, Tritjahjo Danny Soesilo \\ 1,2 Program Studi Bimbingan dan Konseling, Universitas Kristen Satya Wacana, Salatiga \\ Email: puspawany@gmail.com, tritjahjo.danny@staff.uksw.edu
}

\begin{abstract}
Abstrak
Penelitian ini bertujuan untuk meningkatkan minat belajar siswa kelas IX melalui layanan bimbingan kelompok di SMP Kristen 1 Salatiga. Jenis penelitian ini adalah penelitian tindakan bimbingan konseling (PTBK). Subjek penelitian adalah siswa kelas IX yang mempunyai minat belajar kategori rendah yaitu berjumlah 4 siswa. Metode pengumpulan data yang digunakan berupa instrumen penelitian dengan skala minat belajar berdasar teori Hilgard (Slameto, 2010), dan pedoman observasi. Teknik analisis data dalam penelitian ini menggunakan teknik analisis deskripsi komparatif. Hasil penelitian ialah terdapat peningkatan minat belajar siswa melalui 3 tahap siklus pemberian bimbingan kelompok dan berdasar observasi selama proses pembelajaran. Hasil penelitian terbukti bahwa bimbingan kelompok sudah meningkatkan minat belajar keseluruhan siswa.
\end{abstract}

\section{Kata Kunci: Minat Belajar, Bimbingan Kelompok}

\begin{abstract}
This study aims to increase the interest in learning for grade IX students through group guidance services at Christian Middle School 1 Salatiga. This type of research is counseling action research (PTBK). The research subjects were grade IX students who had low interest in learning, which amounted to 4 students. The data collection method used is in the form of a research instrument with a learning interest scale based on Hilgard's theory (Slameto, 2010), and observation guidelines. The data analysis technique in this study uses comparative description analysis techniques. The results of the study are that there is an increase in students' interest in learning through 3 stages of the cycle of group guidance and based on observation during the learning process. The results of the study proved that group guidance has increased students' overall learning interest.
\end{abstract}

Keywords: Learning interest, group counseling

\section{Pendahuluan}

Pada masa sekarang ini, pendidikan sangatlah penting. Hampir setiap manusia di dunia ini, memerlukan pendidikan dalam rangka peningkatan kualitas mutu hidupnya. Oleh karena itu perlunya peningkatan pemahaman mengenai apa itu pendidikan. Menurut Syah (1997) pendidikan merupakan proses menjadikan manusia seutuhnya melalui berbagai kegiatan pembelajaran yang berkaitan dengan kemampuan dan perilaku manusia.

Dalam lingkup sekolah yang disebut pendidikan ialah proses interaksi tatap muka antara peserta didik dengan pendidik yang dimana itu adalah seorang Guru dalam rangka mencapai suatu tujuan pembelajaran. Pembelajaran yang dimaksud ialah berupa pembelajaran secara sistematis, efektif dan realistis.

Dengan adanya seorang pendidik, maka proses pendidikan di sekolah bisa berjalan dengan maksimal. Namun tidak bisa dipungkiri, bahwa pasti dalam proses perjalanan pembelajaran, ada beberapa masalah yang dialami baik oleh peserta didik, maupun oleh para pendidik. Misalnya saja kurangnya daya tarik atau minat belajar yang dialami oleh 
peserta didik. Oleh karena itu fungsi dan tugas seorang pendidik ialah meningkatkan daya tarik atau minat belajar siswa tersebut supaya proses pembelajaran dapat efektif kembali.

Dari hasil penyebaran instrumen pra penelitian yang dilakukan peneliti, dapat dilihat bahwa jumlah peserta didik yang memiliki minat belajar yang rendah dan sangat rendah berjumlah 4 orang. Oleh karena itu, pelaksanaan layanan bimbingan kelompok akan diberikan kepada 4 siswa tersebut sebagai subyek penelitian.

Tabel 1. Sebaran Minat Belajar Siswa Berdasar Pra Penelitian

\begin{tabular}{lcc}
\hline \multicolumn{1}{c}{ Keterangan } & Frekuensi & Jumlah \\
\hline ST (Sangat Tinggi) & $102-119$ & 1 \\
T (Tinggi) & $84-101$ & 10 \\
S (Sedang) & $66-83$ & 15 \\
R (Rendah) & $48-65$ & 4 \\
SR (Sangat Rendah) & $30-47$ & - \\
$\quad$ Total & & 30 \\
\hline
\end{tabular}

Pada penelitian sebelumnya yang diteliti oleh Dewi (2017) dengan judul "Penggunaan Layanan Bimbingan Kelompok untuk Meningkatkan Minat Belajar Siswa Kelas VIII SMP Sriwijaya Bandar Lampung Tahun Pelajaran 2015/2016". Pada penelitian tersebut hasil penelitian menunjukkan bahwa minat belajar siswa dapat ditingkatkan melalui layanan bimbingan kelompok, hal ini ditunjukkan dari hasil analisis data minat belajar siswa dengan menggunakan uji wilcoxon, Hasil pretest dan posttest yang diperoleh $Z_{\text {hitung }}<Z_{\text {tabel }}=-2,807<$ $Z_{\text {tabel } 0,05}=1,645$. Dengan demikian, Ha diterima dan Ho ditolak. kesimpulannya minat belajar dapat ditingkatkan menggunakan layanan bimbingan kelompok pada siswa kelas VIII di SMP Sriwijaya Bandar Lampung Tahun Pelajaran 2015/2016.

Penelitian lainnya yang diteliti oleh Usmani (2016) dengan judul "Pengaruh Bimbingan Kelompok Terhadap Minat Belajar Siswa Kelas VIII di SMP Murni Surakarta Tahun Pelajaran 2016/2017". Hasil penelitian dapat disimpulkan bahwa sebelum ada bimbingan kelompok minat belajar siswa rata-rata hanya $74,64 \%$, sedangkan setelah adanya bimbingan kelompok minat belajar siswa meningkat sebesar $81,29 \%$, nilai $p=0,000(P<0,05)$ yang artinya Ho ditolak, jadi terdapat perbedaan yang signifikan antara minat belajar sebelum dan sesudah bimbingan kelompok. Kesimpulan yang dapat ditarik adalah bimbingan kelompok efektif untuk meningkatkan minat belajar siswa kelas VIII SMP Murni Surakarta.

Berdasarkan hasil wawancara yang telah dilakukan kepada Guru Bimbingan dan Konseling di SMP Kristen 1 Salatiga diperoleh data bahwa peserta didik kelas IX memiliki minat belajar yang kurang. Hal tersebut disebabkan kurangnya motivasi dalam diri untuk belajar, kurangnya pemahaman akan pentingnya pendidikan belajar, kesadaran diri yang kurang dari peserta didik dan pemberian materi dari para guru yang kurang bervariasi. Tujuan penelitian ini adalah untuk meningkatkan Minat Belajar siswa Kelas IX di SMP Kristen 1 Salatiga melalui Layanan Bimbingan Kelompok. Berdasarkan latar belakang dan uraian diatas, maka peneliti tertarik untuk melakukan penelitian dengan judul "Peningkatan Minat Belajar Siswa Kelas IX melalui Layanan Bimbingan Kelompok di SMP Kristen 1 Salatiga.

Menurut Slameto dikutip (dalam Hilgard, 1962) "minat ialah suatu rasa lebih suka dan rasa ketertarikan pada suatu hal atau aktivitas, tanpa ada yang menyuruh." Minat pada dasarnya adalah penerimaan akan suatu hubungan antara diri sendiri dengan sesuatu di luar diri. Semakin kuat atau dekat hubungan itu, semakin besar minat tersebut. Sedangkan menurut Saleh dan Wahab (2005) minat merupakan suatu tindakan yang didorong oleh keinginan diri sendiri yang menghasilkan suatu aktivitas yang menyenangkan. Semakin kuat atau dekat hubungan tersebut, semakin besar minat yang dimilikinya. Namun sebaliknya, semakin lemah hubungan tersebut, maka semakin kecil minat yang dimilikinya. 
Seorang individu yang mempunyai perhatian kepada sesuatu hal, yang biasa disebut minat, maka ia akan berusaha untuk dapat mewujudkannya melalui rangkaian kegiatan yang mengarah dengan perhatiannya itu. adapun menurut Djamarah (2008) mengungkapkan bahwa minat dapat diekspresikan anak didik melalui : a. Menyukai sesuatu daripada yang lainnya, b. Berpartisipasi aktif dalam suatu kegiatan . c. Memberikan perhatian yang lebih besar terhadap sesuatu yang diminatinya dan sama sekali tidak menghiraukan sesuatu yang lain.

Pendapat yang sama yang disampaikan oleh Slameto dikutip (dalam Hilgard, 1962) adalah sebagai berikut: "Minat merupakan sesuatu yang diungkapkan melalui pernyataan dan aksi nyata yang ditunjukan oleh individu dalam suatu kegiatan tertentu serta memiliki perhatian khusus terhadap aktivitas yang disukai". Dalam penelitian ini, peneliti menggunakan pendapat Slameto sebagai teori acuan dalam penyusunan instrumen penelitian.

Menurut Prayitno (2010) “ Bimbingan kelompok adalah suatu kegiatan yang dilakukan oleh sekelompok individu dengan memanfaatkan dinamika kelompok". Hal ini berarti bahwa semua peserta yang terlibat dalam kegiatan kelompok saling berinteraksi, mengeluarkan pendapat secara bebas dan terbuka, menanggapi, memberi saran, dan lain-lain. Interaksi yang berlangsung secara bebas dan terbuka ini dimulai sejak tahap pembentukan hingga tahap pengakhiran.

Menurut Heni (2016) Bimbingan kelompok merupakan kegiatan kelompok yang dilaksanakan dengan memanfaatkan dinamika kelompok untuk individu agar mereka bisa mengemukakan pendapat, menerima pendapat orang lain dan memecahkan permasalahan bersama-sama yang membuat individu bisa mencapai perkembangan yang optimal.

Prayitno (2004) mengemukakan ada dua jenis tujuan layanan bimbingan kelompok, yaitu sebagai berikut : Tujuan umum dari layanan bimbingan kelompok ialah berkembangnya sosialisasi siswa, khususnya kemampuan komunikasi antar anggota kelompok. Melalui layanan bimbingan kelompok, sesuatu yang dapat mengganggu perasaan yang diungkapkan akan diringankan melalui berbagai cara yaitu melalui berbagai masukan dan tanggapan baru. Selain bertujuan sebagaimana bimbingan kelompok, juga bermaksud mengentaskan masalah klien dengan memanfaatkan dinamika kelompok.Bimbingan kelompok bermaksud membahas topik-topik tertentu. Melalui dinamika kelompok yang dilakukan terus menerus, pembahasan topik-topik tersebut akan mendorong pengembangan perasaan, pikiran, persepsi, wawasan dan sikap yang dapat menunjang terwujudnya tingkah laku yang lebih efektif dan optimal.

Minat merupakan suatu hal yang sangat berpengaruh eksistensinya terhadap proses dan hasil belajar. Dengan adanya minat maka segala sesuatu yang dikerjakan serta yang akan dihadapi bisa dicapai dengan baik. Sebaliknya tanpa minat seseorang tidak mungkin melakukan sesuatu. Minat belajar dapat terbentuk dengan adanya dorongan baik dari dalam diri sendiri maupun orang lain., salah satu cara yang dapat dilakukan dalam meningkatkan minat belajar siswa adalah melalui pemberian layanan bimbingan kelompok.

Siswa yang dihadapi dalam bimbingan kelompok bukanlah bersifat individual melainkan terdiri dari beberapa orang yang akan bersama-sama memanfaatkan dinamika kelompok untuk lebih mengembangkan dirinya termasuk mengembangkan minat belajar. Hubungan interaktif antara anggota kelompok akan membuat siswa merasa lebih mudah dan leluasa karena anggotanya merupakan teman sebaya mereka sendiri. Hal ini akan sangat menunjang tercapainya tujuan dalam bimbingan kelompok tersebut yakni meningkatkan minat belajar siswa.

\section{Metode}

Penelitian ini dilaksanakan di SMP Kristen 1 Salatiga. Penelitian ini menggunakan jenis penelitian tindakan bimbingan konseling (PTBK) (Soesilo, 2014). Subyek pada penelitian ini berjumlah 4 siswa yang memiliki minat belajar dalam kategori rendah. Hal ini berdasarkan data pra penelitian yang telah dilakukan sebelumnya. Dalam penelitian ini 
pengumpulan data menggunakan skala likert dan observasi. Skala Likert yang digunakan yaitu skala minat belajar dengan jumlah item sejumlah 30 item pernyataan. Teknik analisis yang digunakan dalam penelitian ini menggunakan teknik analisis deskripsi komparatif. Indikator keberhasilan dalam penelitian ini ialah lebih dari $80 \%$ siswa memiliki minat belajar dengan kategori tinggi.

\section{Hasil dan Pembahasan}

Penelitian ini, menggunakan layanan bimbingan kelompok pada siswa SMP Kristen 1 Salatiga dengan jumlah subjek 4 siswa. Adapun masalah yang telah diteliti adalah apakah layanan bimbingan kelompok dapat meningkatkan minat belajar siswa. Desain penelitian yang digunakan adalah penelitian tindakan bimbingan konseling melali tahapan siklus. Dari hasil analisis jawaban pra penelitian subjek terhadap 30 butir pernyataan minat, dan dari perhitungan diatas maka ditemukan hasil bahwa dari 30 siswa, terdapat 4 siswa memiliki minat belajar dalam kategori yang rendah, 15 siswa memiliki minat belajar dalam kategori sedang, 10 siswa memiliki minat belajar dalam kategori tinggi, dan 1 siswa memiliki minat belajar dalam kategori sangat tinggi.

Sesuai dengan tujuan penelitian yaitu untuk mengetahui peningkatan minat belajar siswa melalui pemberian layanan bimbingan kelompok kepada siswa kelas IX SMP Kristen 1 Salatiga, maka pengumpulan data yang dilakukan meliputi pra penelitian dan tahapan siklus selama 3 kali. Pra penelitian dilakukan sebelum diberikan layanan bimbingan kelompok. Setelah pemberian layanan bimbingan kelompok setiap siklusnya, maka diberikan pengisian instrumen lanjutan untuk mengetahui peningkatan minat belajar yang dimiliki subyek tersebut.

Pada proses pemberian layanan dan observasi siklus I, didapatkan hasil bahwa peserta belum menunjukkan perubahan yang signifikan. Terlihat dalam proses pemberian layanan dan juga proses pembelajaran selama 1 minggu. Hal tersebut dikarenakan pemberian layanan yang terkesan membosankan dan monoton, dan para peserta tampak lesu dan tidak bersemangat dikarenakan jam pembelajaran di sekolah yang padat. Hal tersebut mengakibatkan proses layanan siklus I belum berhasil dan harus dilanjutkan ke tahap berikutnya yaitu siklus II. Sedangkan, pada proses pemberian layanan dan observasi siklus II, didapatkan hasil bahwa peserta mulai menunjukkan perubahan yang bertahap. Peserta mulai lebih aktif dalam merespon dan berdiskusi bersama berkaitan dengan materi yang diberikan, dan lebih memiliki semangat dalam mengikuti pembelajaran. Hal tersebut tidak lepas dari usaha peneliti dalam menggunakan metode layanan yang beragam. Selain itu pemberian reward juga memberikan dampak yang signifikan. Namun begitu, berdasarkan hasil pengolahan data dan observasi, ternyata hasil tersebut belum sesuai dengan indikator keberhasilan yang diinginkan, sehingga proses penelitian dilanjutkan pada tahap berikutnya yaitu siklus ke III. Selanjutnya, pada siklus III peserta menunjukkan peningkatan yang signifikan. Peserta mulai lebih bersemangat dan juga lebih menghargai semua proses dalam pemberian layanan. Tidak hanya disitu, berdasar observasi yang dilakukan oleh observer, peserta juga mengalami perubahan sikap yang lebih baik setelah proses pemberian layanan bimbingan kelompok. Dalam proses pembelajaran, para peserta lebih aktif dalam bertanya dan menanggapi suatu permasalahan di dalam kelas, dan juga antusias meeka lebih baik dibanding sebelum-sebelumnya. Hal tersebut diperkuat dengan teknik dan metode yang diberikan peneliti berupa diskusi dan ceramah sekaligus penambahan media gambar berkaitan dengan tema layanan. Berdasarkan observasi dan pengolahan data yang telah diberikan, didapatkan hasil bahwa proses pemberian layanan telah mencapai target manimal yaitu sudah melampaui indikator keberhasilan. Sehingga penelitian diakhiri dan dinyatakan berhasil dengan keterangan bahwa minat belajar siswa sudah meningkat pada kategori tinggi. 
Tabel 2. Perbandingan Data Presentase Siklus 1, Siklus 2 dan Siklus 3 Minat Belajar Siswa

\begin{tabular}{lcccccc}
\hline \multicolumn{1}{c}{ Kategori } & \multicolumn{2}{c}{ Siklus 1 } & \multicolumn{2}{c}{ Siklus 2 } & \multicolumn{2}{c}{ Siklus 3 } \\
& $\mathrm{F}$ & $\%$ & $\mathrm{~F}$ & $\%$ & $\mathrm{f}$ & $\%$ \\
\hline ST (Sangat Tinggi) & - & - & - & - & - & - \\
$\mathrm{T}$ (Tinggi) & - & - & - & - & 4 & 100 \\
S (Sedang) & 2 & 50 & 4 & 100 & - & - \\
$\mathbf{R}$ (Rendah) & 2 & 50 & - & - & - & - \\
SR (Sangat Rendah) & - & - & - & - & - & - \\
Total & 4 & $100 \%$ & 4 & $100 \%$ & 4 & $100 \%$ \\
& & & & & & \\
\hline
\end{tabular}

Berdasarkan tabel diatas, pemberian layanan bimbingan kelompok ini menggunakan 3 siklus untuk meningkatkan minat belajar siswa, dan pada setiap siklusnya, peserta memiliki peningkatan. Hingga siklus ke 3 minat belajar siswa meningkat hingga dalam kategori tinggi, dibuktikan dengan hasil instrumen dan hasil observasi yang dilakukan oleh kolaborator dimana guru bimbingan konseling sehingga bisa dikatakan pemberian layanan bimbingan kelompok efektif untuk meningkatkan minat belajar siswa.

Hasil penelitian ini membuktikan bahwa teori minat belajar dari Hilgard yaitu " "interest is persisting tendency to pay attention, activities and have active participation in them. Minat merupakan kecenderungan yang tetap untuk memberi perhatian terhadap suatu aktivitas, menikmati aktivitas tersebut, serta turut berpartisipasi aktif di dalamnya. Minat belajar memang dapat ditingkatkan jika dilakukan terus menerus dengan langkah dan tindakan nyata dari siswa itu sendiri, sehingga apa yang diharapkan dalam proses pembelajaran dapat berjalan dengan baik.

\section{Simpulan dan Saran}

Berdasarkan hasil penelitian yang telah dilakukan, maka dapat ditarik kesimpulan bahwa layanan bimbingan kelompok sudah meningkatkan minat belajar siswa kelas IX SMP Kristen 1 Salatiga. Hal tersebut dapat dibuktikan dengan hasil rangkaian dari pra penelitian, siklus 1, siklus 2, dan siklus 3, serta hasil observasi. Dalam mengupayakan peningkatan minat belajar siswa tersebut, maka diberikan layanan bimbingan kelompok selama 3 siklus, dengan beragam metode dan teknik yang digunakan. Peningkatan minat belajar siswa terlihat dari perubahan yang bertahap dari perolehan skor mulai siklus 1 dengan kategori rendah ke siklus 2 dengan kategori relatif sedang dan siklus 3 dengan kategori tinggi. Dapat dilihat bahwa adanya peningkatan yang signifikan dari pemberian layanan mulai tahap 1 sampai tahap 3. Berdasarkan hasil observasi selama 3 siklus, dapat diambil garis besarnya bahwa setelah proses pemberian tindakan berupa layanan bimbingan kelompok, siswa lebih aktif dalam proses pembelajaran, lebih fokus dalam mengikuti proses pembelajaran dan memiliki daya juang yang lebih tinggi dalam mengikuti pembelajaran. Hal tersebut terlihat dari ciri-ciri yang nampak dan ditunjukkan oleh para siswa tersebut. dengan demikian minat belajar dapat ditingkatkan melalui pemberian layanan bimbingan kelompok.

Saran bagi sekolah melalui guru BK adalah perlu diadakan bimbingan kelompok kepada siswa yang memiliki minat belajar yang rendah secara rutin dan berkala, maka minat belajarnya perlu ditingkatkan melalui layanan bimbingan kelompok. Dalam upaya meningkatkan minat belajar siswa, Guru BK dapat menggunakan hasil penelitian ini sebagai acuan dalam meningkatkan minat belajar siswa yang rencana pelaksanaan layanannya tersedia di lampiran penelitian ini. 


\section{Daftar Pustaka}

Astuti, Heni. 2016. Hubungan Bimbingan Kelompok dengan Minat Belajar Siswa Kelas VIII SMP Negeri 1 Pajangan Bantul Tahun Ajaran 2015/2016 dalam jurnal online. (http://repository.upy.ac.id/1307/1/1.\%20ARTIKEL.pdf) diakses 12 Juni 2018 pukul 20.21 WIB.

Djamarah, Syaiful Bahri. 2008. Psikologi Belajar. Jakarta : Rineka Cipta.

Fatmaningsih, Z., Sugiharto, D.Y.P. and Hartati, M.T.S., 2018. MENINGKATKAN SIKAP DISIPLIN BERLALU LINTAS MELALUI LAYANAN BIMBINGAN KELOMPOK DENGAN TEKNIK ROLE PLAYING. Indonesian Journal of Guidance and Counseling: Theory and Application, 7(1).

Haryanti, Usmani. 2016. Pengaruh Bimbingan Kelompok terhadap Minat Belajar Siswa Kelas VIII di SMP Murni Surakarta Tahun Pelajaran 2016/2017 dalam jurnal online. (http://ejournal.utp.ac.id/index.php/JIS/article/download/430/414) diakses pada tanggal 7 Mei 2018 Pukul 17.54 WIB.

Hilgard, Ernet R. 1962. Introduction to Psychology. New York and Burlingame: Harcourt Brace and World Inc.

Prayitno. 2004. Pedoman Bimbingan Kelompok. Padang: Universitas Padang Press.

2010. Layanan Bimbingan dan Konseling Kelompok. Jakarta: Ghalia Indonesia.

Septiyani, Dewi. 2017. Penggunaan Layanan Bimbingan Kelompok untuk Meningkatkan Minat Belajar Siswa Kelas VIII SMP Sriwijaya Bandar Lampung Tahun Pelajaran 2015/2016 (Skripsi) Bandar Lampung : FKIP (http://digilib.unila.ac.id/26605/3/SKRIPSI\%20TANPA\%20BAB\%20PEMBAHASAN.pdf ) diakses pada tanggal 5 Mei 2018 pukul 17.42 WIB.

Shaleh, A.R. dan M.A. Wahab. 2005. Psikologi Suatu Pengantar dalam Perseptif Islam. Jakarta: Prenada Media.

Slameto. 1988. Bimbingan di Sekolah. Salatiga: Universitas Kristen Satya Wacana.

Soesilo, Tritjahjo Danny. 2014. Strategi Pelaksanaan Penelitian Tindakan dalam Bimbingan \& Konseling. Salatiga: Griya Media.

Syah, Muhibbin. 1997. Psikologi Pendidikan dengan Pendekatan Baru. Bandung: PT Remaja Rosdakarya.

Luh Suardani / Meningkatkan Minat \& Hasil Belajar Siswa dalam Berkomunikasi Bahasa Inggris melalui Metode Role Play pada Mata Pelajaran Memproses Reservasi Siswa Lestari, E.D., 2018. Manajemen Persekolahan: Pengembangan Song, Word Map, Game dan Role Play Dalam Pembelajaran Bahasa Inggris Untuk Meningkatkan Speaking Skill Dan Keterlibatan Siswa Kelas III SD Kristen Pelita Bangsa Lumajang. Manajemen Bisnis Kompetensi, 13(1). 